\title{
MICHAŁ CZERENKIEWICZ
}

Biblioteka Narodowa, Warszawa

\section{Czy potrzeba nam dzisiaj polskiego słownika laciny renesansowej i barokowej?}

Przyjęło się uważać, że złoty wiek w kulturze polskiej, owocujący rozwojem literatury łacińskiej i powstającej równolegle twórczości w języku rodzimym, to zarazem czas realizowania postulatu powrotu do antycznych źródeł w postaci najlepszych autorów literatury rzymskiej. O tym, że opinia ta jest słuszna tylko do pewnego stopnia, przekonuje nas lektura wybranego piśmiennictwa łacińskiego z epoki: druków ulotnych, dokumentów urzędowych czy też traktatów naukowych. Z kolei wiek XVII w Rzeczypospolitej to swoisty czas obecności języka łacińskiego w kulturze literackiej i życiu codziennym części mieszkańców państwa przeżywającego wówczas ostatnie chwile swojej świetności. Owa swoistość uzewnętrzniała się w dość sprawnym posługiwaniu się łaciną przez znaczną część stanu szlacheckiego, a także niektórych mieszczan. $\mathrm{W}$ parze $\mathrm{z}$ tą niekwestionowaną kompetencją językową szła również niekiedy daleko posunięta indywidualizacja, która u wczesnonowożytnych pisarzy łacińskich przejawiała się w tworzeniu nowych kolokacji i w przesuwaniu znaczeń poszczególnych leksemów. W tym kontekście warto zastanowić się nad specyfiką łaciny XVI i XVII stulecia na ziemiach polskich, a co za tym idzie opracowaniem leksykonu obejmującego słownictwo używane przez działających wówczas twórców nowołacińskich. W niniejszym tekście podjęta zostanie próba ukazania wybranych kwestii, z jakimi spotykają się osoby zajmujące się łacińską literaturą wczesnonowożytną. Pokrótce scharakteryzowany zostanie również jedyny jak dotąd wydany odrębnie słownik łaciny renesansowej, opracowany przez René Hovena. Zostaną również przedstawione w zarysie założenia leksykonu łacińsko-polskiego obejmującego słownictwo łacińskie używane w XVI oraz XVII stuleciu, wiekach odpowiadających umownie czasom Renesansu i Baroku.

Zapoczątkowany przez Mariana Plezię „Słownik łaciny średniowiecznej w Polsce” jako opus magnum polskiej leksykografii stanowi nieocenioną pomoc dla wszystkich badaczy średniowiecza na terenie ziem polskich. Często bywa również, podobnie jak i inne obszerne słowniki czy to łaciny klasycznej, czy też głównie średniowiecznej, zna- 
czącym wsparciem dla osób zajmujących się szeroko rozumianą literaturą renesansową oraz barokową, jak również późniejszą. Przemiany, jakim podlegał język łaciński w epoce wczesnonowożytnej, doprowadziły z jednej strony do powstania nowego słownictwa, niespotykanego w epoce klasycznej i czasach późniejszych, z drugiej natomiast do zmiany znaczeń leksemów już istniejących, jak również dążenia do wypracowania optymalnej postaci języka. Sięgano w tym celu do uznawanych za najlepszych autorów przedstawicieli złotej bądź srebrnej łaciny. Szczególne uprzywilejowanie przyznawane przez część humanistów stylowi Cycerona wiązało się z oczyszczaniem języka łacińskiego z wpływów średniowiecznych. Przeciwko uwikłaniu łaciny w hermetyczne ramy scholastycznych dysput występował Erazm z Rotterdamu (Swieżawski 2002: 282), który na polu filologii wysoko cenił dokonania Lorenza Valli (Janson 2004: 147; Sondel 2009: XIV $)^{1}$. Ten włoski humanista, dzięki swojej rewerencji wobec słownictwa i całego stylu Arpinaty, zasłynął jako jeden z głównych przedstawicieli cyceronianizmu. Zauważyć jednocześnie wypada, że np. w swoim dziele „Dialogus de recta Latini Graecique sermonis pronuntiatione" Erazm z Rotterdamu (1643: 232-233) poprzez ukazywanie roli autorów łacińskich z różnych epok w tworzeniu własnego zaplecza leksykalnego dawał wyraz dążeniu do naturalnego rozwoju łaciny, czyniąc z niej język mogący być sprawnym narzędziem komunikacyjnym, w pełni dostosowanym do zmieniających się warunków życia społecznego.

Wraz z nadejściem humanizmu w literaturze nowołacińskiej nie zniknęły jednak zupełnie wpływy średniowieczne. Obok tendencji do oddawania myśli za pomocą słownictwa obecnego wyłącznie w epoce złotej łaciny wciąż występowała cała gama leksyki pochodzenia średniowiecznego, w tym terminy techniczne (Domański 2011: 168). Typowe dla teksów wcześniejszych słownictwo, jak i całe charakterystyczne dla nich frazy znaleźć można jeszcze częściej w tekstach wieku XVII. To właśnie wtedy niektórzy autorzy starali się jednocześnie podążać za leksyką Cycerona, naśladować lakoniczność stylu typową dla Tacyta oraz opierać się na auctoritates, którymi byli dla nich wybrani twórcy XVI i XVII stulecia. Reprezentowane przez poszczególnych autorów łacina renesansowa i barokowa - jeżeli w ogóle można użyć takich określeń miały więc postać niejednorodną. Również autorzy naśladujący poetów rzymskich złotego wieku odwoływali się do utworów swoich poprzedników, reinterpretując znaczenia wydawałoby się spetryfikowanych jednostek leksykalnych. Nie ulega wątpliwości, że wskutek gwałtownych przemian gospodarczych i religijnych użytkownicy tego języka stanęli przed wyzwaniami adekwatniejszego nazywania otaczającej ich rzeczywistości, tym pilniejszego, im żarliwsza stawała się dysputa o charakterze religijnym, ustrojowym czy dotycząca merkantylnych aspektów codzienności. Stulecie XVI przyniosło początek kolejnych w dziejach wielkich kontrowersji, w których racje zwolenników reformacji ścierały się ze zwolennikami dawnych wykładni Pisma św. Wszystko to owocowało pogłębieniem lektury tekstów starożytnych, doprecyzowaniem zakresu

\footnotetext{
${ }^{1}$ Na postać tę zwrócił uwagę w trakcie dyskusji na konferencji „Polska leksykografia latynistyczna: historia i perspektywy" prof. Janusz Sondel.
} 
znaczeniowego wybranych pojęć, jak również zmianą znaczenia leksemów już istniejących. Pamięć o tle społeczno-kulturowym oraz kontekście, w jakim dany leksem został użyty, dla łacińskich utworów wczesnonowożytnych stanowi jeszcze bardziej podstawowy niż w wypadku dzieł antycznych prerekwizyt w pracy translatorskiej.

Często wskazuje się na fakt, że zdecydowana większość słownictwa łacińskiego występuje w utworach nowołacińskich oczywiście w znaczeniu znanym z łaciny klasycznej. Niemniej w tekstach powstających m.in. w XVI wieku pojawia się także słownictwo, które nie znajduje poświadczenia we wcześniejszym materiale leksykalnym. Przykład zmiany pola semantycznego danego leksemu można zaobserwować w wypadku tekstowych realizacji rzeczownika tessera. W łacinie klasycznej wyraz ten oznacza m.in. czworograniastą tabliczkę. „Glossarium mediae et infimae Latinitatis” podaje, że tessera to ,signum bellicum, quadrangulum" (tamże: 83). Notowany pod hasłem biglietto we włosko-łacińskim „Lexicon Recentis Latinitatis” (1992: 92) rzeczownik ten opatrzony jedną z przydawek: vectoria, itineraria lub viaria oznacza bilet uprawniający do odbycia podróży. W tym samym haśle spotykamy również m.in. wyrażenia tessera theatrica oraz tessera palaestrica. Zwróćmy uwagę, że w słowniku tym pod hasłem blasone nie został odnotowany rzeczownik tessera, który w siedemnastowiecznych herbarzach oznacza „herb”. Takie znaczenie występuje w dziele Silvestra Petrasancty „Tesserae gentilitiae”. Z kolei Szymon Okolski w herbarzu „Orbis Polonus” pisze o herbach szlacheckich, używając sformułowania tessera nobilium. Podobnie rzecz przedstawia się z wywodzącym się z języka włoskiego rzeczownikiem impresa mogącym oznaczać on emblemat, jak również herb. Analogiczna sytuacja występuje w wypadku rzeczownika arma, oznaczającego w łacinie średniowiecznej herbową tarczę, a w łacinie nowożytnej herb ${ }^{2}$. Pojawiające się w tekstach nowołacińskich tworzonych na terytorium Rzeczypospolitej Obojga Narodów słownictwo obejmuje także wyrazy wywodzące się z języków słowiańskich. Do nich należą formy takie, jak: tivunus (ciwun), vlodarius (włodarz), vaivoda (wojewoda) czy zuparius vel zupparius (żupnik).

Część wyrazów nabiera nowego znaczenia. Rzeczownik satrapia oznacza województwo lub krainę geograficzną i nie ma nacechowania pejoratywnego. Comitia to sejmik, a comitia regni to sejm walny. Musaeum to miejsce pracy naukowej, własny gabinet. Gravitas w nowożytnych tekstach z zakresu fizyki to siła ciążenia (Stroh 2013: 252).

Już w późnośredniowiecznej łacinie występują nazwy obecne w starożytności, jednak o zmienionym znaczeniu. Przykładem może być rzeczownik Sarmata. Niektóre wyrazy przejęte zostały do łaciny średniowiecznej, a następnie nowożytnej z języka greckiego: toparcha (przełożony miejsca) czy archistrategos (generał zakonu). Powstaje również cała grupa wyrazów złożonych najczęściej z form nazw własnych oraz rzeczownika mastix, np. Erasmomastix.

Do innej grupy należy leksyka powstała bądź też nabierająca nowego znaczenia wskutek przemian, jakie zachodziły w życiu społeczno-religijnym. Tutaj przytoczyć

\footnotetext{
${ }^{2}$ Fakt ten wskazała autorowi prof. Barbara Milewska-Waźbińska.
} 
można rzeczowniki minister, pastor, superintendens, Lojolita czy Ignatianus. Używane bywa obecne również w średniowieczu wyrażenie beatissimus pater.

Już kilka powyższych obserwacji wskazuje na pożytki wynikające z posługiwania się w praktyce translatorskiej tekstów nowołacińskich, obok słowników łaciny klasycznej, również leksykonami uwzględniającymi łacińskie słownictwo wczesnonowożytne.

Jak dotąd istnieje jeden tylko wydany drukiem naukowy w ścisłym tego słowa znaczeniu słownik łaciny nowożytnej, ograniczonej w zasadzie do XVI stulecia, oraz kilka pomniejszych opracowań. Wkrótce nakładem wydawnictwa Brill wydany zostanie tego rodzaju leksykon ${ }^{3}$. Warto zarazem wspomnieć o szesnastowiecznym dziele „Farrago sordidorum verborum” Corneliusa Crocusa, współwydanym z komentarzem Erazma z Rotterdamu do „Elegantiae linguae Latinae” Valli. Znamienne jest rozwinięcie tytułu pracy Crocusa: „Augiae stabulum repurgatum”. Z roku 1755 pochodzi „Corruptae Latinitatis index" Williama Masseya. Autor zawarł w nim słownictwo poklasyczne, również to używane w XVI i XVII stuleciu.

Między innymi z dzieła Crocusa korzystał belgijski uczony René Hoven (1922-2010). Jego „Słownik prozy łacińskiej Renesansu”, „Lexique de la Prose Latine de la Renaissance", wydano po raz pierwszy w roku 1994. Spośród dostępnych mu słowników autor opierał się m.in. na „Dictionnaire latin-français” (I wyd. 1934 i nast.) Félixa Gaffiota (Hoven 1994: VIII, X-XII). Podczas prac nad kolejną edycją swojego leksykonu Hoven korzystał już z wydania słownika Gaffiota z 2000 roku, tzw. „Le Grand Gaffiot”. Kolejna edycja słownika łaciny renesansowej, zmieniona i rozszerzona, opracowana z pomocą m.in. Laurenta Graileta, ukazała się w roku 20064. Poszczególne hasła posiadają $\mathrm{w}$ tej edycji zarówno objaśnienia w języku francuskim, jak i angielskim. Wydanie to objęło materiał leksykalny zaczerpnięty z dzieł ok. 230 autorów. W pierwszej wersji Hoven uwzględnił utwory 150 pisarzy nowołacińskich. Pod względem chronologicznym listę otwiera Petrarka. Hoven przyjął w tym miejscu cezurę czasową umownie wyznaczającą początek epoki nowołacińskiej, zaproponowaną przez Societas Internationalis Studiis Neolatinis Provehendis oraz aprobowaną przez Josepha IJsewijna. Joseph IJsewijn w dwutomowym podręczniku do studiów neolatynistycznych dokonał charakterystyki słownictwa i stylu tekstów tworzonych od początku włoskiego Renesansu.

Już w samym tytule prekursorskiej pracy Hovena pojawia się wyznacznik formalny tekstów, które stanowią materiał źródłowy dla haseł występujących w leksykonie. W przedmowie do drugiego wydania autor wspomniał o dostępnej w postaci elektronicznej i sukcesywnie uzupełnianej „Liście słów nowołacińskich”, „Neulateinische Wortliste. Ein Wörterbuch des Lateinischen von Petrarca bis 1700” Johanna Rammingera. Zaznaczył jednocześnie, że z racji zbyt późnego zaznajomienia się z podanym wykazem nie włączył wspomnianych haseł do swojego słownika. Wraz z drugim wydaniem słownika dołączony został artykuł poświęcony słownictwu nowołacińskiemu Tomasza Morusa.

\footnotetext{
${ }^{3}$ Korektą tego słownika zajął się p. Antoine Haaker, któremu zawdzięczam wiadomość o prowadzonych pracach.

${ }^{4}$ Dziękuję dr. Markowi Janickiemu za umożliwienie mi zapoznania się z drugim wydaniem słownika.
} 
Prace nad słownictwem nowołacińskim podejmował również Richard J. Schoeck. Warto jeszcze wspomnieć o „Instrumentum lexicographicum” sukcesywnie publikowanym na łamach „Humanistica Lovaniensia” i opracowywanym obecnie przez Dirka Sacré (zob. Sacré 2010: 467-469). Inny niderlandzki badacz, Marc van der Poel, analizując słownik Hovena, wystąpił z postulatem przygotowania nowego leksykonu łaciny wczesnonowożytnej przez zespół autorów (Van der Poel 2007). Celem tego przedsięwzięcia byłoby zintensyfikowanie indywidualnych prac, jakie prowadzą osoby zajmujące się leksyką nowołacińską. Do ich grona należał m.in. David Morgan, którego rozpoczętą pracę kontynuuje Patrick M. Owens. Niewątpliwie leksykon Hovena należy do najważniejszych dzieł z tego zakresu.

Słownik Hovena podaje pewną grupę słów używanych także przez polskich humanistów. Część z tych słów występuje również w łacinie klasycznej i średniowiecznej. Wśród wspomnianych twórców na czoło wysuwa się Andrzej Frycz Modrzewski i jego dzieło „De republica emendanda”. W pracy Hovena znaleźć można słowa użyte przez polskiego humanistę. Spośród rzeczowników są to: bogaty włościanin: cmeto, -onis; obojętność: adiaphoria, -ae; ksiądz służący przy ołtarzu: altarista, -ae; zwyczaj właściwy dworzanom: aulicismus, $-i$; dowódca tysiąca żołnierzy: chiliarchus, $-i$; równa godność: condignitas, -atis; pisemna replika: contrascriptum, - $i$; niewielka poprawka: correctiuncula, -ae; dziesięciokrotność: decuplum, - $i$; bycie bez obuwia: discalceatio, -onis; rozrzutnik: dilapidator, -oris; podzielność: divisibilitas, -atis; ukazanie się: emersio, -onis; nakaz religijny nałożony na siebie: ethelotreskia, -ae; ocena: expensio, -onis; żołnierz uzbrojony w wiklinową tarczę: gerophoron, -orontis; janczar: ianizaris, -is; przemiana elementu w inny: transelementatio. Wśród rzeczowników wyróżnić można formy odprzymiotnikowe: szacowna osoba: honorabilitas, -atis (tua honorabilitas), wielmożność: illustritas, -atis. Wśród przysłówków zwrócić warto uwagę na takie znaczenia jak: w sposób ograniczony w przestrzeni: circumscriptive; całkowicie: comprehense. Frycz Modrzewski posługuje się też następującymi przymiotnikami: ograniczony w przestrzeni: circumscriptivus; towarzyszący: concomitativus, -a, - um; mierzalny: dimensivus, - $a$, -um; mogący być przewróconym: evertibilis, -is; heretycki: haereticalis, - is; sprawiający uzyskanie czegoś: impetratorius, - a, -um (zmiana znaczenia z: ,pragnący coś uzyskać”).

Słownik Hovena przytacza również kilka wyrazów zaczerpniętych bezpośrednio z dzieła Mikołaja Kopernika (zob. także: Domański 2011: 168-169). Są wśród nich terminy techniczne pochodzenia greckiego, np. apogaeum. W leksykonie wspominany jest również działający w XVI wieku na terenie Królestwa Polskiego Krzysztof Hegendorph. Wśród używanych przez niego wyrazów pojawia się przymiotnik genialis mający m.in. znaczenie: originalis, primigenius, primordialis (Hoven 1994: 149), a zatem inne niż spotykane w łacinie klasycznej. U Hegendorpha występuje on w junkturze geniale peccatum (w znaczeniu: originale peccatum).

Zmiany znaczeniowe poszczególnych wyrazów oraz występujące w łacińskich tekstach wczesnonowożytnych neologizmy kierują naszą uwagę na projekt polskiego „Słownika łaciny renesansowej i barokowej”. Podstawową sprawą byłaby kwestia usta- 
lenia w miarę ścisłego zakresu chronologicznego oraz tematycznego słownika. Powinien on notować przede wszystkim te znaczenia, które rzadko występują w literaturze antycznej lub brak ich poświadczenia w dotychczasowych leksykonach. Użyte w roboczej wersji tytułu leksykonu przymiotniki określają mniej lub bardziej precyzyjnie $z$ jednej strony zakres chronologiczny materiału, $z$ drugiej natomiast wskazują na stylistykę tekstów łacińskich często odmienną od stylistyki tekstów antycznych. Właściwie więc byłby to słownik łaciny zasadniczo od połowy XVI do początków XVIII wieku. Szesnastowieczne słownictwo występujące przed rokiem 1550 raczej nie byłoby w nim notowane ze względu na prowadzone nad nim badania w ramach opracowywania „Słownika łaciny średniowiecznej w Polsce”, chyba że artykuły hasłowe dla poszczególnych nowołacińskich leksemów pochodzących z pierwszej połowy XVI stulecia nie zostały jeszcze opracowane.

Godne rozważenia jest szczególne zwrócenie uwagi na autorów łacińskich polskiego kręgu kulturowego. Poza nie dość licznymi wyjątkami, takimi jak np. Jan Kochanowski czy Maciej Kazimierz Sarbiewski, w pracach zachodnich badaczy łacińskiej literatury wczesnonowożytnej bywają on niezauważeni. W odróżnieniu od pierwszego drukowanego słownika do tekstów nowołacińskich kolejna publikacja obejmowałaby również słownictwo obecne w poezji. Starając się przygotować reprezentatywny dla polskiej literatury nowołacińskiej leksykon, trudno byłoby w nim pominąć słownictwo występujące u szeregu mniej lub bardziej znanych poetów. To właśnie w ich utworach dostrzec można ścisły związek nie tylko ze starożytnością klasyczną, lecz także ze współczesną im sytuacją społeczną, w której tworzyli swoje poezje. Objęcie pracami również tekstów pisanych mową wiązaną mogłoby zostać zaznaczone w podtytule leksykonu. Zakres słownictwa sięgałby także do czasów średniowiecznych. Jak już zauważono, zarówno w czasach Renesansu, jak i Baroku autorzy sięgali niekiedy do konstrukcji wypracowanych w tekstach średniowiecznych. Zachowywali wówczas zarówno charakterystyczne dla owych tekstów struktury składniowe, jak i zasób słownictwa.

Wśród autorów z Rzeczypospolitej stanowiących podstawę do badań obok wspomnianych już Kochanowskiego i Sarbiewskiego znaleźć powinni się twórcy tacy, jak na przykład: Klemens Janicki, Marcin Kromer, Andrzej Frycz Modrzewski, Stanisław Orzechowski, Stanisław Hozjusz, Stanisław Sarnicki, Sebastian Fabian Klonowic, Szymon Szymonowic, Szymon Starowolski, Szymon Okolski, Albert Ines, Wespazjan Kochowski, Andrzej Maksymilian Fredro, Stanisław Herakliusz Lubomirski czy Jan Heweliusz ${ }^{5}$. Osobne miejsce należy się Mikołajowi Kopernikowi oraz działającemu w Lesznie spolonizowanemu przyrodnikowi szkockiego pochodzenia Janowi Jonstonowi. Lista ta jest oczywiście otwarta. Skrutynizacją powinny zostać objęte zarówno stare druki, jak też wybrane rękopisy, zwłaszcza w odniesieniu do stulecia XVII, które bywa określane jako „wiek rękopisów”. Szczególnie interesujące ustalenia poczynić

\footnotetext{
${ }^{5} \mathrm{Na}$ tego ostatniego autora zwróciła uwagę w trakcie konferencji poświęconej polskiej leksykografii latynistycznej prof. Jadwiga Waniakowa.
} 
można w wyniku lektury sylw szlacheckich. Idiolekt poszczególnych autorów stanowi w tym wypadku cenny materiał źródłowy.

Pomocą będą z pewnością teksty nowołacińskie twórców z Rzeczypospolitej, pisane z myślą o czytelniku zagranicznym. Autorzy przedstawiają w nich ustrój swojego kraju, podając niekiedy polskie tłumaczenia trudniejszych ich zdaniem wyrazów. Do tej grupy utworów zaliczyć można dzieło „Eques Polonus” Szymona Starowolskiego. Również Krzysztof Hartknoch w swoim „Respublica Polonica” przekazuje polskie odpowiedniki łacińskich słów.

Czerpiąc z doświadczeń polskiej leksykografii oraz opierając się na wzorcach zachodnich, w tym na „A Glossary of Later Latin to 600 A.D.” A. Soutera (Oxford 1947, reprint 1997), należałoby powołać doradczy zespół interdyscyplinarny, obejmujący historyków, w tym historyków nauki, a także polonistów i teologów. Wymienieni przedstawiciele nauk szczegółowych to tylko kilka grup badaczy, jacy mogliby być zaproszeni do przygotowywania słownika. Ich zadaniem byłoby przygotowanie najczęściej występujących terminów technicznych z zakresu reprezentowanej dyscypliny. Interdyscyplinarny charakter prac nad słownikiem wynikałby z istoty samej dyscypliny, wciąż jeszcze konstytuującej się, a mianowicie neolatynistyki. Szczególną rolę w przygotowywaniu słownika mieć powinni wydawcy staropolskich tekstów nowołacińskich. W swoim artykule poświęconym studiom nowołacińskim Hans Helander wskazuje na znaczący przyrost słownictwa naukowego w badanej epoce (Helander 2001: 34). Szwedzki uczony postuluje zwrócenie szczególnej uwagi na łacińską prozę naukową.

Do rozważenia pozostaje kwestia obecności osobnego indeksu z nazwami własnymi, zwłaszcza geograficznymi. W razie jego obecności powinien on przyjąć formę typowego artykułu hasłowego w słowniku, bez informacji o charakterze encyklopedycznym.

Przedstawiony w zarysie projekt słownika przede wszystkim do łacińskich autorów staropolskich wymaga opracowania w kwestiach praktycznych i szczegółowych, począwszy od ustalenia osób odpowiedzialnych za to przedsięwzięcie, a na zagadnieniach dotyczących redagowania haseł skończywszy. Z pewnością polska leksykografia latynistyczna wraz ze wzrostem zainteresowania studiami nowołacińskimi wśród badaczy wypracuje z czasem słownik będący odpowiedzią na zgłaszane postulaty środowiska neolatynistów.

\section{Bibliografia}

A Glossary of Later Latin To 600 A.D., 1957, ed. A. Souter, Oxford.

Corruptae Latinitatis index or a Collection of barbarous words and phrases which are found in the works of the most celebrated modern writers in Latin [...], 1755, ed. W. Massey, London.

Crocu s C., 1536, Farrago sordidorum verborum, [w:] Paraphrasis seu potius Epitome inscripta d. Erasmo Roterod. luculenta iuxta ac brevis in Elegantiarum libros Laurentii Vallae, ab ipso iam recognita, cum Gallica tum dictionum, tum locutionum expositione. Cui addita est Farrago sordidorum verborum sive Augiae stabulum repurgatum per Cornelium Crocum, Parisiis. 
Czerenkiewicz M., Ry czek W., 2013, Studia (neo)Latina rediviva. Kilka uwag i postulatów odnośnie do neolatynistyki, Terminus, t. 15, z. 3 (28), s. 335-358.

D o mańs ki J., 2011, Scholastyka i początki humanizmu w myśli polskiej XV wieku, Warszawa.

Glossarium mediae et infimae Latinitatis conditum a Carolo Dufrense domino Du Cange, auctum a monachis ordinis S. Benedicti, cum supplementis integris d. P. Carpenterii, Adelungii, aliorum suisque digessit G. A. L. Henschel, [...] editio nova aucta a Léopold Favre, t. 8: T-Z, 1887, Du Cange et alii, Niort.

Eras mu s Rotte r od a mu s, 1643, Dialogus de recta Latini Graecique sermonis pronuntiatione, Lugduni Batavorum.

Hel a n d e r H., 2001, Neo-latin Studies: Significance and Prospects, Symbolae Osloenses 76, s. 5-44.

Hoven R., 1994, Lexique de la Prose Latine de la Renaissance, Leiden-New York-Köln.

— 2006, Lexique de la prose latine de la Renaissance, avec la collaboration dé Laurent Grailet, deuxième édition revue et considérablement augmentée, English Translation by Coen Maes, revised by Karin Renard-Jadoul, Leiden-Boston.

J a n s o n T., 2004, A Natural History of Latin, translated and adapted into English by Merethe Damsgård Sørensen and Nigel Vincent, Oxford.

Korpanty J., Wolanin H., 2001, Przedmowa, [w:] Słownik łacińsko-polski. A-H, t. 1, red. naukowy J. Korpanty, Warszawa.

Lexicon eorum vocabulorum quae difficilius Latine redduntur, ed. III, 1955, ed. A. Bacci, Roma.

Lexicon Morganianum (Morgan Latin Lexicon): http://www.wyomingcatholiccollege.com/faculty-pages/ patrick-owens/index.aspx (dostęp: 21.06.2015).

Lexicon recentis Latinitatis, editum cura operis fundati cui nomen „Latinitas”, moderator Carolus Egger, vol. I, A-L, 1992, in Urbe Vaticana.

Lexicon recentis Latinitatis, editum cura operis fundati cui nomen „Latinitas”, moderator Carolus Egger, vol. II, M-Z, 1997, in Urbe Vaticana.

Petras ancta S., 1638, Tesserae gentilitiae [...] ex legibus fecialium descriptae, Romae.

Plezi a M., 2011, Projekt zasad redagowania słownika polskiej łaciny średniowiecznej, [w:] M. Plezia, Scripta minora. Łacina średniowieczna i Wincenty Kadłubek, Kraków, s. 23-46.

Ramminger J., Neulateinische Wortliste. Ein Wörterbuch des Lateinischen von Petrarca bis 1700: $\mathrm{http}: / /$ ramminger.userweb.mwn.de/neulateinische_wortliste.htm (dostęp: 04.05.2014).

- 2011, The role of classical, medieval, and Renaissance lexicography in the development of neo-Latin: some examples from the Latin works of Marcus Marulus, Studi Umanistici Piceni XXXI, s. 75-86, por. http://ramminger.userweb.mwn.de/biblio_lrz/ramminger_marulus_lexicography.pdf (dostęp: 30.09.2014).

S a c ré D., 2010, Instrumentum lexicographum, Humanistica Lovaniensia. Journal of Neo-Latin Studies, 59, s. 467-469.

Stro h W., 2013, Łacina umarła, niech żyje łacina! Mała historia wielkiego języka, tłum. A. Arndt, wstęp E. Wesołowska, Antyk u Tuwima - A. Arndt, Poznań.

S o n del J., 2009, Przedmowa, [w:] Słownik łacińsko-polski dla prawników i historyków, Kraków.

S w i ė̇a w s k i S., 2002, Między średniowieczem a czasami nowymi. Sylwetki myślicieli XV wieku, Warszawa.

Van der Poel M., 2007, recenzja słownika: R. Hoven, Lexique de la Prose Latine de la Renaissance, Leiden-Boston, 2006: http://bmcr.brynmawr.edu/2007/2007-03-12.html (dostęp: 05.05.2014). 


\section{SUMMARY}

Do We Need Today the Polish Dictionary of Renaissance and Baroque Latin?

Keyw o rd s: Neo-Latin lexicography, Neo-Latin studies, Renaissance, Baroque.

Słowa kluczowe: leksykografia nowołacińska, neolatynistyka, Renesans, Barok.

The paper is an outline of the issue of Neo-Latin vocabulary in the context of dictionaries covering words taken from early-modern Latin texts. Apart from the "Dictionary of Renaissance Latin from prose sources" by René Hoven and some very useful minor Neo-Latin word-lists scholars dealing with the works of $16^{\text {th }}$ and $17^{\text {th }}$ century do not have specialized Latin lexicons on mainly Renaissance and Baroque literature. Even dictionaries on classical, mediaeval or ecclesiastical Latin sometimes are helpful only to some extent. The author proposes preparing the early modern Neo-Latin dictionary mainly from the works by the Polish authors. 